\title{
Pengaruh Capital Adequacy Ratio , Biaya Operasional Pendapatan Operasional dan Net Operational Margin terhadap Financing to Deposit Ratio pada Bank Umum Syariah di Indonesia Tahun 2016-2018
}

\author{
Moch Fajar Suryo Atmojo *, Nurfahmiyati \\ Prodi Ilmu Ekonomi, Fakultas Ekonomi dan Bisnis, Universitas Islam \\ Bandung, Indonesia. \\ *fajarsuryoatmojo@gmail.com, fyatie03@yahoo.com
}

\begin{abstract}
Sharia Banking as an economic sub-system certainly will directly or indirectly have an impact on the development and economic growth of a country. Sharia Commercial Bank (BUS) is a bank that conducts business activities based on sharia principles and in its activities provides services in payment traffic as referred to in Act Number 21 of 2008 concerning Sharia Banking. The health of a bank is very important for all parties involved both the owner, manager (management) of the bank, the banking service user community, monetary authorities, and other parties. This study was conducted to examine the effect of CAR, BOPO, and NOM on Financing to Deposit Ratio (FDR) of Sharia Commercial Banks in Indonesia in 2016-2018. This type of research uses quantitative research with a verification approach. The data used are secondary data taken from the FSA using time series data. Data processing uses Eviews version 7.0 with Ordinary Least Square (OLS) method.The results showed that the CAR variable partially had a negative effect and the BOPO and NOM variables had a positive and significant effect on FDR at Islamic Commercial Banks in Indonesia. From the estimation results obtained R-square of 0.733707 , which means 73.37 percent variation of changes in Financing to Deposit Ratio (FDR) of Sharia Commercial Banks is explained by variations in changes in CAR, $\mathrm{BOPO}$, and NOM. While the remaining 26.63 percent explained by other variables not included in the equation model.
\end{abstract}

Keywords: Sharia Commercial Banks, FDR, CAR, BOPO, NOM.

\begin{abstract}
Abstrak. Perbankan Syariah sebagai suatu sub sistem ekonomi tentunya baik secara langsung maupun tidak langsung akan memberikan dampak terhadap perkembangan dan pertumbuhan ekonomi suatu negara. Bank Umum Syariah (BUS) adalah bank yang menjalankan kegiatan usahanya berdasarkan prinsip syariah dan dalam kegiatannya memberikan jasa dalam lalu lintas pembayaran sebagaimana dimaksud dalam UndangUndang Nomor 21 Tahun 2008 tentang Perbankan Syariah. Kesehatan suatu bank merupakan hal yang sangat penting bagi seluruh pihak yang terkait baik pemilik, pengelola (manajemen) bank, masyarakat pengguna jasa bank, otoritas moneter, serta pihak lainnya. Penelitian ini dilakukan untuk menguji pengaruh CAR, BOPO, dan NOM terhadap Financing to Deposit Ratio (FDR) Bank Umum Syariah di Indonesia Tahun 2016-2018. Jenis penelitian menggunakan penelitian kuantitatif dengan pendekatan verifikatif. Data yang digunakan adalah data sekunder yang diambil dari OJK menggunakan data runtut waktu (time series). Pengolahan data menggunakan program Eviews versi 7.0 dengan metode Ordinary Least Square (OLS). Hasil penelitian menunjukkan variabel CAR secara parsial berpengaruh negatif dan variabel BOPO dan NOM berpengaruh positif dan signifikan terhadap FDR pada Bank Umum Syariah di Indonesia. Dari hasil estimasi diperoleh Rsquare sebesar 0.733707 , yang berarti 73.37 persen variasi perubahan pada Financing to Deposit Ratio (FDR) Bank Umum Syariah dijelaskan oleh variasi perubahan pada CAR, BOPO, dan NOM. Sementara sisanya 26.63 persen diterangkan oleh variabel lain yang tidak masuk ke dalam model persamaan.
\end{abstract}

Kata Kunci: Bank Umum Syariah, FDR, CAR, BOPO, NOM. 


\section{A. Pendahuluan}

Bank Umum Syariah (BUS) adalah bank yang menjalankan kegiatan usahanya berdasarkan prinsip syariah dan dalam kegiatannya memberikan jasa dalam lalu lintas pembayaran sebagaimana dimaksud dalam Undang-Undang Nomor 21 Tahun 2008 tentang Perbankan Syariah. Selama tahun 2016-2018 perkembangan BUS di Indonesia mengalami peningkatan yang dapat dilihat pada tabel di bawah ini :

Tabel 1. Perkembangan Perbankan Syariah Tahun 2016-2018

\begin{tabular}{|l|c|c|c|}
\hline \multicolumn{1}{|c|}{ Tahun } & $\mathbf{2 0 1 6}$ & $\mathbf{2 0 1 7}$ & $\mathbf{2 0 1 8}$ \\
\hline Jumlah BUS & 13 & 13 & 14 \\
\hline Jumlah Kantor & 1.869 & 1.825 & 1.875 \\
\hline Aset BUS (Miliar Rupiah) & 254.184 & 288.026 & 316.691 \\
\hline
\end{tabular}

Sumber: Statistik Perbankan Indonesia, Publikasi OJK Desember 2017 dan 2018 (data diolah)

Dari segi kelembagaan, tercatat terjadi peningkatan yang cukup signifikan pada Bank Umum Syariah sebesar 7,69 persen. Pada segi kantor cabang, BUS mengalami peningkatan sebesar 0,32 persen. Berkurangnya jumlah cabang karena bank di Indonesia memang melakukan efisiensi.

Besar kecilnya ukuran perbankan dapat dilihat dari total asetnya. Total aset merupakan salah satu indikator perkembangan Syariah yang akan menentukan kontribusi industri perbankan Syariah terhadap perbankan nasional. Apabila ukuran perbankan besar maka total aset yang dimiliki perusahaan juga besar (Wardana dan Widyarti, 2015). Jumlah total aset BUS pada tahun 2016-2018 mengalami peningkatan setiap tahunnya menunjukkan nilai yang cukup signifikan . Pada rentan waktu tahun 2016-2018 terjadi peningkatan sebesar 24,59 persen atau sebesar Rp. 62.507.

Efektifitas sebuah bank dalam menjalankan fungsinya sebagai lembaga intermediasi dapat dilihat dari nilai Financing to Deposit Ratio (pada bank Syariah) bank tersebut. Semakin besar Financing to Deposit Ratio (FDR) sebuah bank maka semakin efektif bank tersebut dalam menjalankan fungsinya sebagai lembaga intermediasi (Jamaludin dan Kuriyah, 2017). Berikut merupakan perkembangan FDR bank umum syariah di Indonesia periode 2016-2018 yang dapat dilihat pada tabel di bawah ini.

Tabel 2. Financing To Deposit Ratio (Fdr) Bank Syariah Dalam Kurun Waktu 2016-2018

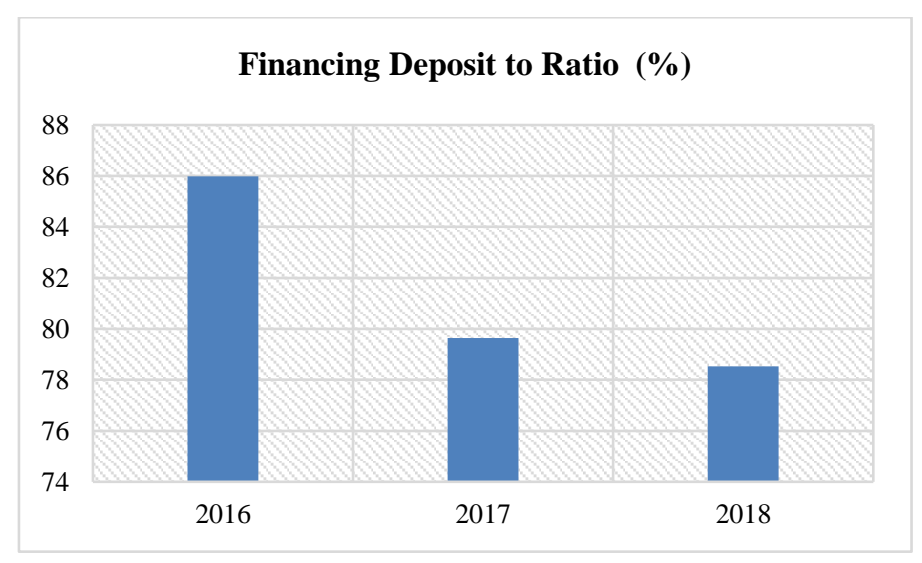

Sumber: Statistik Perbankan Indonesia, Publikasi OJK Desember 2017 dan 2018 (data diolah) 
Sejak tahun 2017 FDR perbankan syariah mengalami penurunan yang mana nilai tersebut berada pasa standard sehatnya yaitu $75 \%-85 \%$. Artinya, perbankan syariah di Indonesia sudah semakin efektif dalam kinerjanya yang dapat dipengaruhi oleh variabel CAMEL itu sendiri. Variabel yang penulis ambil dalam penulisan ini yaitu Capital Adequancy Ratio (CAR), Biaya Operasional terhadap Pendapatan Operasional (BOPO), dan Net Operating Margin (NOM).

Berdasarkan latar belakang yang telah diuraikan, maka perumusan masalah dalam penelitian ini sebagai berikut: "bagaimana pengaruh dan besarnya pengaruh CAR, BOPO, dan NOM terhadap FDR pada Bank Umum Syariah di Indonesia?". Selanjutnya, tujuan dalam penelitian ini diuraikan dalam pokok-pokok sbb.

1. Untuk mengidentifikasi dan menganalisis pengaruh CAR, BOPO, dan NOM terhadap FDR pada Bank Umum Syariah di Indonesia periode 2016-2018.

2. Untuk mengidentifikasi dan menganalisis besarnya pengaruh CAR, BOPO, dan NOM terhadap FDR pada Bank Umum Syariah di Indonesia periode 2016-2018.

\section{B. Landasan Teori}

Bank syariah adalah bank yang berdasarkan pada asas kemitraan, keadilan, transparansi, dan universal serta melakukan kegiatan usaha perbankan berdasarkan prinsip syariah. Fungsi Bank Islam secara garis besar tidak berbeda dengan bank konvensional yakni sama-sama sebagai lembaga intermediasi yang menghimpun dana dari masyarakat dan menyalurkan kembali danadana tersebut kepada masyarakat yang membutuhkannya dalam bentuk fasilitas pembiayaan. Perbedaan pokoknya terletak dalam perlakuan dan jenis keuntungan yang diambil bank dari transaksi-transaksi yang dilakukannya.

Kesehatan suatu bank tidak mempengaruhi kepentingan pemilik bank saja, tetapi kesehatan suatu bank juga menjadi kepentingan berbagai pihak, seperti pengelola, masyarakat, investor maupun pengawas. Sehubungan dengan itu, Bank Indonesia sebagai pengawas seluruh bank yang ada di Indonesia menetapkan kriteria tertentu untuk menilai kesehatan bank, termasuk bank syariah (Prasetiyo, 2012).

Dalam penelitian ini, menggunakan salah satu kinerja keuangan dari sisi profitabilitas yaitu Financing to Deposit Ratio (FDR). Menurut Muhammad (2005). Financing to Deposit Ratio (FDR) adalah perbandingan antara pembiayaan yang diberikan oleh bank dengan dana pihak ketiga yang berhasil dikerahkah oleh bank.

Berdasarkan beberapa penelitian yang telah dilakukan terdapat hasil yang berbeda-beda. Dengan adanya perbedaan hasil dari penelitian terdahulu (research gap) maka perlu diadakan penelitian lebih lanjut mengenai hubungan antara Capital Adequacy Ratio (CAR), Biaya Operasional Pendapatan Operasional (BOPO) dan Net Operating Margin (NOM) terhadap Financing Deposit Ratio (FDR) pada Bank Umum Syariah di Indonesia.

\section{Variabel Bebas}

Beberapa faktor yang dapat berpengaruh terhadap kinerja keuangan perusahaan, khususnya perbankan syariah di Indonesia, yaitu : CAR, BOPO, dan NOM.

Rasio Capital Adequacy Ratio (CAR) memproxy-kan penilaian terhadap aspek permodalan bank. Rasio CAR adalah kecukupan modal yang menunjukkan kemampuan bank dalam mempertahankan modal yang mencukupi dan kemampuan manajemen bank dalam mengidentifikasi, mengukur, mengawasi, dan mengontrol risiko-risiko yang dapat berpengaruh terhadap besarnya modal bank. (Wibowo, 2008).

Biaya Operasional terhadap Pendapatan Operasional (BOPO) merupakan rasio yang menunjukkan besaran perbandingan antara beban atau biaya operasional terhadap pendapatan operasional suatu perusahaan pada periode tertentu (Riyadi, 2006). BOPO telah menjadi salah satu rasio yang perubahan nilainya sangat diperhatikan terutama bagi sektor perbankan mengingat salah satu kriteria penentuan tingkat kesehatan bank oleh Bank Indonesia adalah besaran rasio ini.

Net Operating Margin adalah rasio yang menggambarkan Pendapatan Operasional Bersih sehingga diketahui kemampuan ratarata aktiva produktif dalam menghasilkan laba (Rivai 
dkk, 2012). Rasio NOM mengindikasikan kemampuan bank dalam menghasilkan pendapatan bunga bersih dengan penempatan aktiva produktif (Taswan, 2009).

\section{Keterkaitan CAR terhadap FDR}

Koefisien yang positif menunjukkan bahwa ketika nilai CAR mengalami kenaikan diikuti dengan meningkatnya nilai FDR. Pengaruh yang tidak signifikan menunjukkan bahwa variabel CAR tidak signifikan pada level 5\% dengan arah koefisien yang positif. Dapat disimpulkan bahwa CAR berpengaruh positif dan tidak signifikan terhadap FDR Bank Umum Syariah di Indonesia.

\section{Keterkaitan BOPO terhadap FDR}

Dalam penelitian Astuti (2016) variabel BOPO berpengaruh positif dan signifikan terhadap FDR. Hal ini di sebabkan karena bank umum syariah tetap melakukan pembiayaan untuk menutup beban operasial yang tinggi. Hal ini didukung dengan modal sendiri yang dimiliki bank umum syariah yang cukup kuat untuk mengatasi apabila terjadi resiko.

\section{Keterkaitan NOM terhadap FDR}

Berdasarkan hasil pengujian diketahui bahwa secara parsial Net Operating Margin berpengaruh positif dan signifikan terhadap Financing to Deposit Ratio pada Bank Umum Syariah di Indonesia. Semakin tinggi NOM akan berdampak pada meningkatnya FDR pada Bank Umum Syariah di Indonesia.

\section{Hasil Penelitian dan Pembahasan}

Jenis penelitian ini menggunakan penelitian kuantitatif dengan pendekatan verifikatif. Penelitian ini menggunakan metode Ordinary Least Square (OLS). OLS merupakan metode estimasi fungsi regresi yang paling sering digunakan. Kriteria OLS adalah "Line of Best Fit" atau dengan kata lain jumlah kuadrat dari deviasi antara titik-titik observasi dengan garis regresi adalah minimum. Dalam model regresi linear memiliki beberapa asumsi dasar yang harus dipenuhi untuk menghasilkan estimasi yang BLUE, yaitu : Homoscedastic, no-multicollinearity dan no-autocorrelation.

Tabel 3. Alokasi Hasil Estimasi Model Pengaruh Car, Bopo, Dan Nom Terhadap Fdr Bank Umum Syariah di Indonesia

\begin{tabular}{|c|c|c|c|c|}
\hline Variabel & Coefficient & Std. Error & t-Statistic & Prob. \\
\hline C & -48.49364 & 46.89388 & -1.034114 & 0.3088 \\
\hline CAR & -0.823121 & 0.306260 & -2.687650 & 0.0113 \\
\hline BOPO & 1.463512 & 0.437508 & 3.345107 & 0.0021 \\
\hline NOM & 8.890616 & 2.954861 & 3.008810 & 0.0051 \\
\hline R-squared & & & Durbin-Watson stat & 0.528562 \\
F-statistic & 29.38951 & & & \\
\hline
\end{tabular}

Sumber: diolah dengan menggunakan eviews versi 7.0 Indonesia.

Model pengaruh CAR, BOPO, dan NOM terhadap FDR Bank Umum Syariah di 
Tabel 4. Perbandingan T-Tabel Dengan T-Hitung

\begin{tabular}{|c|c|c|c|c|}
\hline Variabel & t-Statistik & t-tabel $(\boldsymbol{\alpha}=\mathbf{0 . 0 5})$ & $\mathbf{H}_{\mathbf{0}}$ & Keterangan \\
\hline CAR & -2.687650 & -2.03693 & $\mathrm{H}_{0}$ ditolak & Signifikan \\
\hline BOPO & 3.345107 & 2.03693 & $\mathrm{H}_{0}$ ditolak & Signifikan \\
\hline NOM & 3.008810 & 2.03693 & $\mathrm{H}_{0}$ ditolak & Signifikan \\
\hline
\end{tabular}

Sumber: Hasil estimasi model dengan menggunakan eviews versi 7.0

\section{Pengaruh CAR terhadap FDR}

Berdasarkan hasil pengujian secara parsial dapat diketahui bahwa Capital Adequacy Ratio (CAR) berpengaruh negatif dan signifikan terhadap Financing to Deposit Ratio (FDR) pada Bank Umum Syariah di Indonesia. Hal ini terlihat dari hasil membandingkan antara t-hitung dengan t-tabel $(\alpha)$. Sementara jika dilihat dari arah hubungan antara CAR dengan FDR adalah negatif. Artinya ketika CAR meningkat maka FDR menurun.

\section{Pengaruh BOPO terhadap FDR}

Hasil penelitian selanjutnya adalah hasil pengujian secara parsial yang menjelaskan bahwa Biaya Operasional Pendapatan Operasional (BOPO) berpengaruh positif dan signifikan terhadap Financing to Deposit Ratio (FDR) pada Bank Umum Syariah di Indonesia.Semakin kecil BOPO berarti semakin efisien biaya operasional yang dikeluarkan bank yang bersangkutan sehingga kemungkinan suatu bank dalam kondisi bermasalah semakin kecil dan semakin banyak kredit yang dapat disalurkan.

\section{Pengaruh NOM terhadap FDR}

Berdasarkan hasil pengujian secara parsial diperoleh bahwa Net Operating Margin (NOM) berpengaruh positif dan signifikan terhadap Financing to Deposit Ratio (FDR) . Hal ini terlihat dari hasil membandingkan antara t-hitung dengan t-tabel $(\alpha)$.Hal ini berarti peningkatan NOM akan menyebabkan peningkatan FDR dan sebaliknya penurunan NOM akan menyebabkan penurunan FDR. Penyebabnya adalah semakin tinggi NOM mengindikasikan semakin tinggi pendapatan bersih suatu bank yang berasal dari aktiva produktifnya.

\section{Interpretasi Koefisien Determinasi (R2)}

Koefisien determinasi adalah koefisien yang menghitung yang menghitung seberapa besar variasi dari variabel terikat (dependen) dapat dijelaskan oleh variabel bebas (independen). Adapun hasil dari koefisien determinasi (R2) dalam penelitian ini sebesar 0.733707 atau 73.37 persen. Artinya 73.37 persen variasi pada FDR (variabel terikat) dapat dijelaskan oleh variabel CAR, BOPO, dan NOM (variabel bebas). Sementara sisanya 26.63 persen ditentukan oleh variabel lain yang tidak dimasukkan kedalam model.

\section{Besar pengaruh CAR, BOPO, dan NOM terhadap FDR Bank Umum Syariah di Indonesia}

Berdasarkan hasil estimasi diperoleh nilai koefisien variabel Capital Adequacy Ratio (CAR) sebesar 0.823121 (dibulatkan menjadi 0.82) dengan tanda negatif. Artinya jika CAR mengalami kenaikan sebesar 1 persen maka FDR Bank Umum Syariah akan meningkat sebesar 0.82 persen atau sebaliknya dengan asumsi variabel lain dianggap tetap (Ceteris Paribus). Jika dilihat dari besarnya nilai koefisien yang lebih kecil dari 1 menunjukkan bahwa perubahan CAR menimbulkan perubahan yang kurang berarti terhadap FDR pada BUS di Indonesia.

Berdasarkan hasil estimasi diperoleh nilai koefisien variabel Biaya Operasional Pendapatan Operasional (BOPO) adalah positif 1.463512 (dibulatkan menjadi 1.46). Artinya jika BOPO mengalami kenaikan sebesar 1 persen maka ROA Bank Umum Syariah akan meningkat sebesar 1.46 persen atau sebaliknya dengan asumsi variabel lain dianggap tetap (Ceteris Paribus). Jika dilihat dari besarnya nilai koefisien yang lebih besar dari 1 menunjukkan 
bahwa perubahan BOPO menimbulkan perubahan yang relatif besar terhadap FDR pada BUS di Indonesia. Berdasarkan hasil estimasi diperoleh nilai koefisien variabel Net Operating Margin sebesar 8.890616 (dibulatkan menjadi 8.89) dengan tanda positif. Artinya jika BOPO mengalami kenaikan sebesar 1 persen maka ROA Bank Umum Syariah akan meningkat sebesar 8.89 persen atau sebaliknya dengan asumsi variabel lain dianggap tetap (Ceteris Paribus). Jika dilihat dari besarnya nilai koefisien yang lebih besar dari 1 menunjukkan bahwa perubahan NOM menimbulkan perubahan yang relatif besar terhadap FDR pada BUS di Indonesia.

\section{Kesimpulan}

Berdasarkan hasil penelitian mengenai Capital Adequacy Ratio (CAR), Biaya Operasional terhadap Pendapatan Operasional (BOPO) dan Net Operating Margin (NOM) terhadap pengaruh Financing to Deposit Ratio (FDR) pada Bank Umum Syariah di Indonesia tahun 20162018, maka dapat ditarik beberapa kesimpulan sebagai berikut:

1. Dari hasil penelitian menunjukkan variabel CAR, BOPO dan NOM secara bersama-sama berpengaruh signifikan terhadap FDR. Artinya, setiap perubahan yang terjadi pada variabel independen yaitu CAR, BOPO dan NOM secara simultan atau bersama-sama akan berpengaruh pada FDR pada Bank Umum Syariah di Indonesia.

2. Berdasarkan hasil perhitungan Interpretasi Koefisien Determinasi (R2) diketahui bahwa nilai R square adalah sebesar 0.733707 . Angka tersebut menandakan bahwa variasi dari variabel independen (CAR, BOPO dan NOM) terhadap FDR adalah sebesar 73.37 persen. Sedangkan sisanya sebesar 26.63 persen dijelaskan oleh variabel-variabel lain yang tidak dimasukkan dalam analisis penelitian ini.

3. Secara parsial variabel CAR BOPO dan NOM memiliki pengaruh terhadap FDR dan variabel yang paling dominan mempengaruhi FDR berdasarkan hasil penelitian sebagai berikut:

- Variabel CAR berpengaruh negatif dan signifikan terhadap FDR pada Bank Umum Syariah di Indonesia.

- Variabel BOPO berpengaruh positif dan signifikan terhadap FDR pada Bank Umum Syariah di Indonesia

- Variabel NOM berpengaruh positif dan signifikan terhadap FDR pada Bank Umum Syariah di Indonesia

4. Dari hasil estimasi model diketahui hasil koefisien dari setiap variable yaitu CAR sebesar -0.823121, BOPO sebesar 1.463512 dan NOM sebesar 8.890616.

\section{E. Saran}

\section{Saran Teoritis}

1. Peneliti selanjutnya diharapkan dapat menambahkan kriteria sebagai penentuan sampel, sehingga sampel yang digunakan menjadi lebih spesifik dan diharapkan tidak menghambat penelitian dalam mendapatkan hasil yang maksimal. Dan lebih jeli dalam menentukan variabel intervening.

2. Penelitian ini diharapkan dapat digunakan sebagai referensi dan teori bagi mahasiswa yang akan melakukan penelitian sejenis khususnya mahasiswa Ilmu Ekonomi. 


\section{Saran Praktis}

1. Penelitian ini dapat digunakan dalam mengevaluasi untuk terus meningkatkan rasio tingkat capital, yaitu Capital Adequacy Ratio. Hal ini karena CAR merupakan faktor penting dalam menyalurkan kredit/pembiayaan kepada masyarakat juga memerlukan modal. Modal bank harus dapat juga digunakan untuk menjaga kemungkinan timbulnya risiko, diantaranya risiko yang timbul dari kredit/pembiayaan itu sendiri, sehingga Bank Umum Syariah dapat mengoptimalkan kemampuan dan menjalankan fungsi intermediasi dengan baik.

2. Diharapkan adanya kebijakan-kebijakan bagi perbankan khususnya perbankan syariah sehingga antara pemerintah, penyedia modal dan masyarakat dapat berjalan selaras dalam meningkatkan perekonomian masyarakat secara merata. Karena bisa dilihat sekarang, kebijakan yang dibuat beberapa bank dalam menentukan kriteria peminjaman modal lebih banyak menguntungkan bagi pengusaha besar dan cukup merugikan usaha kecil untuk mendapatkan modal dari bank karena dianggap kemampuan untuk mengembalikan pinjaman adalah kecil.

\section{Daftar Pustaka}

[1] Astuti, Fitri. 2016. Pengaruh Efisiensi Usaha, Risiko Keuangan dan Kepercayaan Masyarakat terhadap Kemampuan Penyaluran Pembiayaan pada Bank Umum Syariah di indonesia Tahun 2011-2014. Jurnal Ekonomi \& Keuangan Islam, Vol. 2 No. 2

[2] Jamaludin,Nur dan Siti Kuriyah. 2017. Profit Sharing Financing, FDR, Dan NPF Dan Pengaruhnya Terhada Profitabilitas Bank Umum Syariah. Islaminomic. Vol. 7 No. 2.

[3] Muhammad. 2005. Manajemen Bank Syariah. Yogyakarta: UPP AMP YKPN

[4] Prasetiyo, Luhur . 2012. Analisis Rentabilitas Bank Umum Syariah Di Indonesia. Kodifikasia, Volume 6 No. 1 Tahun 2012

[5] Rivai, Veithzal, dkk. 2012. Islamic Banking and Finance Edisi Pertama. Yogyakarta: BPFE

[6] Riyadi, Slamet. 2006. Banking Asset and Liability Management. Jakarta. Penerbit Fakultas Ekonomi Universitas Indonesia.

[7] Taswan. 2006. Manajemen Perbankan. Yogyakarta: UPP STIM YPKP

[8] Wibowo. 2008. Manajemen Kinerja. Jakarta: Raja Grafindo Persada. 